serological tests were obtained in 69 of these patients. Of the remaining 31 patients, significant antibody titres to toxoplasma were obtained in five and to cytomegalovirus in two. In 24 patients the cause of the illness was undiagnosed.

In our series the level of atypical lymphocytosis was critical: all 19 patients with atypical lymphocytes forming over $45 \%$ of the total leucocyte count gave a positive result in the Paul-Bunnell-Davidsohn test; and all 27 patients with over $40 \%$ of atypical lymphocytes were either positive in the PaulBunnell-Davidsohn test or had significant titres of $\operatorname{IgM}$ anti-Epstein-Barr virus antibodies. Thus it appears that high levels of lymphocytes (over $40 \%$ ) are diagnostic of infectious mononucleosis, whereas at lower levels of atypical lymphocytes an appreciable number of patients do not have infectious mononucleosis.

D O HO-YEN

Haematology Section,

University Department of Pathology,

Ninewells Hospital

${ }^{1}$ Pfeiffer E. Jahrbuch für Kinderheilkunde 1889;29 257-64.

2 Sprunt TP, Evans FA. Bull Johns Hopkins Hosp 1920

${ }^{3}$ Ho-Yen DO, Martin KW. $\mathcal{F}$ Infect: (in press.)

\section{Hypoplastic anaemia associated with legionnaires' disease}

SIR,-Dr D O Ho-Yen in his letter (1 March, p 647) about our case report (9 February, p 366) comments on the possible role of co-trimoxazole in producing hypoplastic anaemia and gives reference to two papers to support his view. However, in the first paper ${ }^{1}$ patients were treated with co-trimoxazole for at least 12 months (our patient received this drug for five days), and although they had depressed reticulocytes, neutrophils, and platelets their marrow did not show hypoplasia. In the second paper ${ }^{2}$ two patients with aplastic anaemia are referred to but further details are not given.

The second point made by Dr Ho-Yen is that chronic acquired aplastic anaemia cannot be excluded. We agree with this point; but, because of the clearcut effect of the infection on the marrow during the acute phase and the subsequent apparent recovery when the infection was controlled, we speculated on a possible permanent effect of the legionnaire organism on the marrow.

\section{J Hajiroussou} R C JosHI \footnotetext{
Cripps Postgraduate Medical
Centre, General Hospital

Northampton NN1 5BD
}

${ }^{1}$ Dawborn JK, Castaldi PA, Kilgour A, Parkin JD, 2 Palter AJ. Med $\mathcal{F}$ Aust 1973; i :spec suppl, 70-4.

\section{Genital herpes}

SIR,-Your comprehensive leading article on genital herpes ( 7 June, p 1335) concludes by stating that the most important aspects of the management of this disease are "sexual abstinence to avoid infecting a partner and tracing sexual partners who may be at risk." Advising sexual abstinence has never been a very successful method of preventing any sexually transmitted disease and is likely to be especially ineffective in genital herpes as the disease may be transmitted by patients in the absence of signs or symptoms. Most patients can, or will, refrain from sexual intercourse when genital lesions are present but one cannot expect them to remain continent in their absence. The risk of infection in such circumstances is admittedly much less but it is still present.

Finally, what does one do when "a potentially infected partner has been traced ?" If examination reveals no sign of the illness there is no guarantee that subclinical infection (and hence potential infectivity) has taken place. On the other hand, if overt disease is found, as is made clear in your leading article, there is no really effective remedy. Unfortunately many, if not all, patients with genital herpes remain intermittently infectious for long periods, if not for life. If in addition they are sexually promiscuous then such a combination of events provides an almost impossible situation to control. What is needed is a drug which is capable of dealing with the virus present in the sensory ganglia, and possibly acyclovir may offer some hope here.

\section{Genitomedical Clinic,}

Addenbrooke's Hospita

Cambridge CB2 2QQ

\section{Review Body award}

SIR,-The Review Body has recommended that doctors and dentists should receive an increase of $18.7 \%$ in their remuneration to offset the effects of inflation, while other Health Service workers have been warned that their increase cannot be more than $14 \%$. There are good reasons for the higher award to doctors and dentists but the fact that they are receiving more must give rise to deep resentment. All the partners in this practice are agreed that they would like to see doctors and dentists given the same increase to offset inflation as other Health Service workers. This would mean a reduction of $4.7 \%$ in the increase already agreed, but that should not present an insuperable obstacle and it would surely help to create a happier spirit within the service. We feel that many doctors and dentists must share our view and we would ask our leaders to find out if this is so.

J A P PEIRCE D I AITKEN W R TUDOR-THOMAS

T J MORRIS Swanage, Dorset BH19 1DL ROBERT A HARDIE

SIR,-Have the Yaxley doctors (7 June, p 1379) forgotten that we have waited for two years for this award, which, including an amount for inflation, finally brings us up to date I should be interested to know to which charity, and this includes the Inland Revenue, they would like to give the top $5 \%$ of the award which they are willing to have delayed by one year.

Huntingdon, Cambs PE18 OHD

JOHN V KILBY

SIR,-I was very encouraged to read in you journal (7 June, p 1379) that Dr C J R Hart and others are willing to accept a delay of one year in the implementation of the top $5 \%$ of the recent pay award. As a consultant I would like to suggest to my colleagues throughout the NHS that we forego $10 \%$ of the proposed new award until there is evidence of significant improvement in the country's economy.

We claim to be a caring profession-can we not give practical proof of this by showing concern for the underprivileged, our schoolchildren, and the aged, who are so vulnerable in the present serious economic situation, and set an example to the nation?

GEORGE S TURNER

Queen Elizabeth Group Hospitals,

Gateshead, Tyne and Wear

\section{Two-tier registrar grade}

SIR,-As a consultant in a peripheral hospital in an industrial northern city, I would like to express my apprehension at Dr John Nabarro's plan for a two-tier registrar grade (17 May, p 1237). We have already seen the failure to redistribute senior registrar and registrar posts from the London teaching hospitals to the rest of the country. My fear is that the influential teaching hospitals and those hospitals that geographically are able to participate in rotational training schemes will hold on to the higher-tier registrar posts and the peripheral hospitals will be further disadvantaged by being recognised only for lower-tier general training posts.

It will mean that only candidates of inferior quality will apply for peripheral posts and anyone who shows unexpected merit will have the greatest difficulty in moving to a recognised training post.

All trainee specialists must realise that they may eventually become peripheral consultants and it is in their interest to ensure that training posts are not confined to a few centres.

J F PATRICK

Wakefield, WFZ 6DW

\section{Subsidising private patients?}

SIR,-In this hospital private patients admitted for coronary angiography and discharged on the same day pay the hospital authorities $£ 112 \cdot 80$. If they remain overnight their total charge is only $f 63$. The cost for catheterisation, excluding medical fees, at the only private catheter laboratory in London is at present £235. At a time when the National Health Service is short of money the Minister should surely take steps to change the method of charging so that we no longer subsidise overseas patients but make a profit.

\section{Ronald B PRIDIE}

Harefield Hospital,
Uxbridge, Middx UB9 6JH

\section{London's medicine}

SIR,-I read Dr Gareth Jones's letter (22 March, p 870) with interest. The thesis which he propounds, that medical students trained in a particular vicinity will remain to practise in that area, is a well-known myth. Even though the University Grants Committee and the DHSS have poured millions of pounds into the new Cardiff Hilton-sorry, I mean the University Hospital of Wales-this has 